\title{
EARLY LIFE STAGES OF FISH AND THE RELATIONSHIPS WITH ZOOPLANKTON IN A TROPICAL BRAZILIAN RESERVOIR: LAKE MONTE ALEGRE
}

\author{
MESCHIATTI, A. J. and ARCIFA, M. S. \\ Departamento de Biologia, FFCLRP, Universidade de São Paulo, Av. Bandeirantes, 3900, \\ CEP 14040-901, Ribeirão Preto, SP, Brazil \\ Correspondence to: Marlene Sofia Arcifa, Departamento de Biologia, FFCLRP, Universidade de São Paulo, \\ Av. Bandeirantes, 3900, CEP 14040-901, Ribeirão Preto, SP, Brazil, e-mail: marcifa@usp.br \\ Received July 31, 2000 - Accepted February 23, 2001 - Distributed February 28, 2002
}

(With 6 figures)

\begin{abstract}
For evaluating the trophic relationship between early life stages of fish and zooplankton in Lake Monte Alegre, fish distribution and feeding habits have been studied in areas with and without macrophytes. In the first of these areas, 356 specimens belonging to 8 species, mostly juveniles, were caught by a sieve. Another 35 specimens, belonging to 4 species, were caught by gill nets and seine in areas lacking macrophytes. Their diets were composed of aquatic insects, microcrustaceans, rotifers, detritus, and other aquatic invertebrates. Microcrustacean prey were mainly littoral or benthic dwellers, found in the highest proportion in specimens of 7-20 mm SL. Most fish species have parental care, which could explain the absence of planktonic larvae. Early life stages of fish do not exert a predation pressure on the lake zooplankton.
\end{abstract}

Key words: young fish, feeding habits, zooplankton predation, reservoir, South America.

\section{RESUMO}

\section{Fases jovens de peixes e a predação sobre o zooplâncton em um reservatório tropical brasileiro: Lago Monte Alegre}

Para avaliar a relação trófica entre as fases jovens de peixes e o zooplâncton no Lago Monte Alegre, a distribuição e os hábitos alimentares dos peixes foram estudados em áreas com e sem macrófitas. Nas macrófitas, foram capturados com peneira 356 exemplares de 8 espécies, na maioria jovens. Outros 35 exemplares de 4 espécies foram capturados em áreas sem macrófitas, com redes de espera e arrasto. A dieta dos peixes foi composta de insetos aquáticos, microcrustáceos, rotíferos, detritos e outros invertebrados aquáticos. Os microcrustáceos predados foram principalmente formas litorâneas ou bentônicas, consumidos em maior proporção pelos espécimens de 7-20 mm CP. A maioria das espécies apresenta cuidado parental, o que explica a ausência de larvas planctônicas. As fases jovens de peixes não representam uma força de predação sobre o zooplâncton.

Palavras-chave: fases jovens de peixes, predação sobre o zooplâncton, reservatório, América do Sul.

\section{INTRODUCTION}

In Brazilian water bodies, planktivorous fish are scarce and the littoral zone is more heavily occupied by fish fauna than is the limnetic (AraújoLima et al., 1995; Arcifa \& Northcote, 1997). A common assumption is that in the early life stages, fish are planktivores, but it is important to investigate the fish and prey distributions to evaluate the real trophic relationship between fish and zooplankton.

Several species of fish in temperate regions have pelagic larvae (Petering \& Van Den Avyle, 1988; Turner et al., 1994), which are planktivores, 
mainly zooplanktivores, strongly influencing zooplanktonic organisms (Sabo \& Kelso, 1991; Miranda $\& \mathrm{Gu}, 1998)$. But higher densities of fish larvae can be found in aquatic vegetation than in open water (Paller, 1987; Conrow et al., 1990; Floyd et al., 1984).

In Brazil, migratory species of fish have eggs and/or pelagic larvae, which are considered planktivores (Nakatani et al., 1997), although feeding studies very often do not identify either true planktonic prey or littoral ones. In the Amazonian region, planktonic microcrustaceans are an important dietary item for juveniles of some species, but the number of planktivorous species is low (Santos \& Ferreira, 1999). Larvae and juveniles of Characiforms and Siluriforms associated with macrophytes can feed on cladocerans, copepods, and rotifers (Sazima \& Zamprogno, 1985; Machado-Allison \& Garcia, 1986; Araújo-Lima et al., 1986; Mol, 1995). A detailed study on the composition of microcrustaceans consumed by larvae and young fish associated with macrophytes showed that they are littoral and/or benthic dwellers in a floodplain lake (Meschiatti et al., 2000).

Therefore, strong fish predation on the pelagic zooplankton in most Brazilian lentic waters is doubtful.
In Lake Monte Alegre, predation pressure exerted by young and adult fish in areas lacking macrophytes is low, since most species are not planktivores (Arcifa \& Meschiatti, 1993). An exception are adult Tilapia rendalli, which can be planktivore, mainly phytoplanktivore (Arcifa \& Meschiatti, 1996).

In order to evaluate the predation pressure of early life stages of fish on zooplankton, this study focused on fish composition, distribution, and abundance in littoral macrophytes and open areas, as well as their feeding habits and prey availability.

\section{STUDY AREA}

Lake Monte Alegre $\left(21^{\circ} 11^{\prime} \mathrm{S}, 47^{\circ} 43^{\prime} \mathrm{W}\right)$ is a small, shallow, eutrophic reservoir (area 7 ha, $\mathrm{Z}_{\max }=5 \mathrm{~m}, \overline{\mathrm{z}}=2.9 \mathrm{~m}$ ). Located in Ribeirão Preto, São Paulo State, at an altitude of $500 \mathrm{~m}$, it resulted from damming the Laureano Creek, of the Pardo River basin, in 1942. Macrophytes cover ca. 10\% of its area (Fig. 1), Eichhornia azurea predominating. The region is characterized by a dry-cool season (May-September) and a wet-warm one (October-April). Abiotic and biotic features of the lake can be found in Arcifa et al. (1990, 1992, 1998).

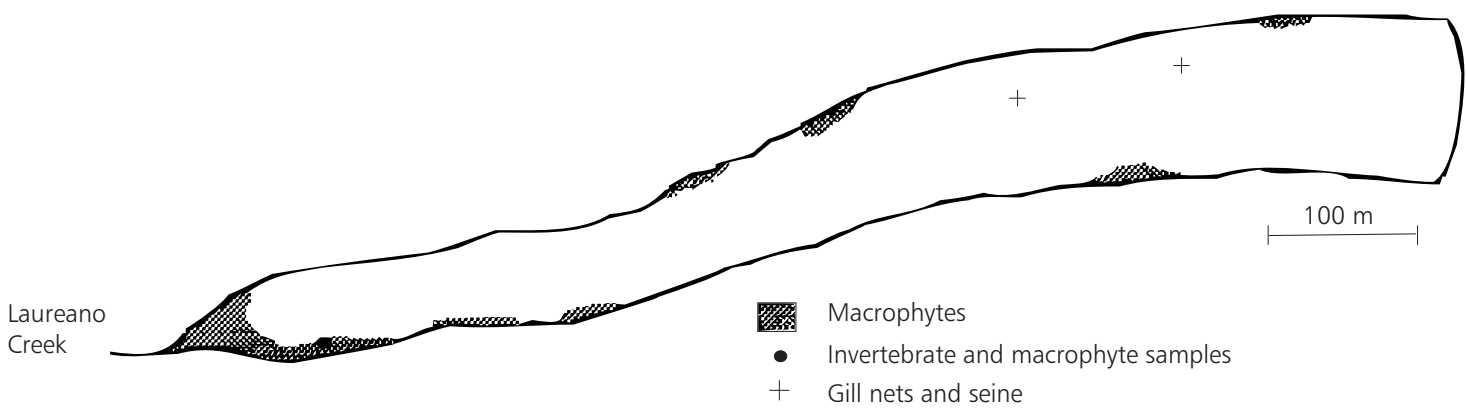

Fig. 1 - Lake Monte Alegre and the area covered by macrophytes (shaded), the station of macrophyte and prey samplings $(\bullet)$, and the area of gill net and seine samplings $(+)$.

\section{MATERIAL AND METHODS}

Larvae and young fish were sampled monthly from September 1998 to August 1999. In macrophytes, they were collected with a sieve $80 \mathrm{~cm}$ in diameter and $3 \mathrm{~mm}$ mesh, during the day, in the shaded areas shown in Fig. 1. An ichthyoplankton net $1.4 \mathrm{~m}$ in length, $0.4 \mathrm{~m}$ of mouth diameter, and $400 \mu \mathrm{m}$ mesh was used for sampling in the open area near sunset. It was pulled $c a$. $20 \mathrm{~m}$ behind a motor boat, in horizontal hauls. The volume filtered by the net, measured by a flowmeter (Gene- 
ral Oceanics 2030R) attached to its mouth, averaged $83 \mathrm{~m}^{3}$. All samples were fixed in formalin $10 \%$, and the fish measured in standard length (SL). Relative abundance of fish in macrophytes was based on individuals caught in $5 \mathrm{~m}^{2}$.

Close to the macrophytes, water samples were taken with a bilge pump, delivering 30 1. $\mathrm{min}^{-1}$, and filtered in a $60 \mu \mathrm{m}$ net, from November 1998 onwards, in order to evaluate potential prey availability for fish. Organisms were counted in three $1 \mathrm{ml}$ subsamples. From January to August 1999, macrophytes were also sampled, washed, and the suspended material filtered in 400 and $60 \mu \mathrm{m}$ nets and fixed in formalin $4 \%$.

Larger organisms caught in the $400 \mu \mathrm{m}$ net were all counted, whereas the smaller ones caught in the $60 \mu \mathrm{m}$ net were counted in three $2.5 \mathrm{ml}$ subsamples. Macrophytes were dried, at $90^{\circ} \mathrm{C}$ for $48 \mathrm{~h}$, and weighed.

For catching fish in areas lacking macrophytes, additional samplings were made with gill nets and a seine, in February and April 2000, respectively.

Gill nets of 1,2 , and $5 \mathrm{~m}$ height were set parallel to the margin at sunset for $4 \mathrm{~h}$. Gill nets were composed of the following meshes: 30,40 , $50,60,80$, and $110 \mathrm{~mm}$, diagonally stretched. Seine hauls were made with a net of $1.4 \times 8.4 \mathrm{~m}$ and 3 $\mathrm{mm}$ mesh, at a distance of $18 \mathrm{~m}$ from the margin, covering an area of approximately $150 \mathrm{~m}^{2}$. Specimens were frozen and later measured and weighed, after defrosting.

Fish diets were studied by stomach content analyses, evaluating the area occupied by the items in a counting chamber according to a subjective method (Hyslop, 1980). Calculations were made according to Zaret \& Rand (1971). Frequency of occurrence of items was also evaluated.

\section{RESULTS}

\section{Potential prey availability in macrophytes and the surrounding area}

Insects, nematodes, and microcrustaceans were the most abundant organisms among invertebrates associated with macrophytes (Fig. 2).

Insects were mostly represented by chironomids, and in a much smaller proportion (5\%) by mayflies, odonates, and caddisflies. Ostracods represented $75 \%$ of the microcrustaceans, followed by chydorid and macrothricid cladocerans (13\% and $7 \%$, respectively), adult copepods (Microcyclops sp.) and nauplii (3.5\%), and the cladoceran Simocephalus sp. (1.5\%), all littoral organisms.

In the water near the macrophytes, rotifers predominated followed by copepods and cladocerans (Fig. 3).

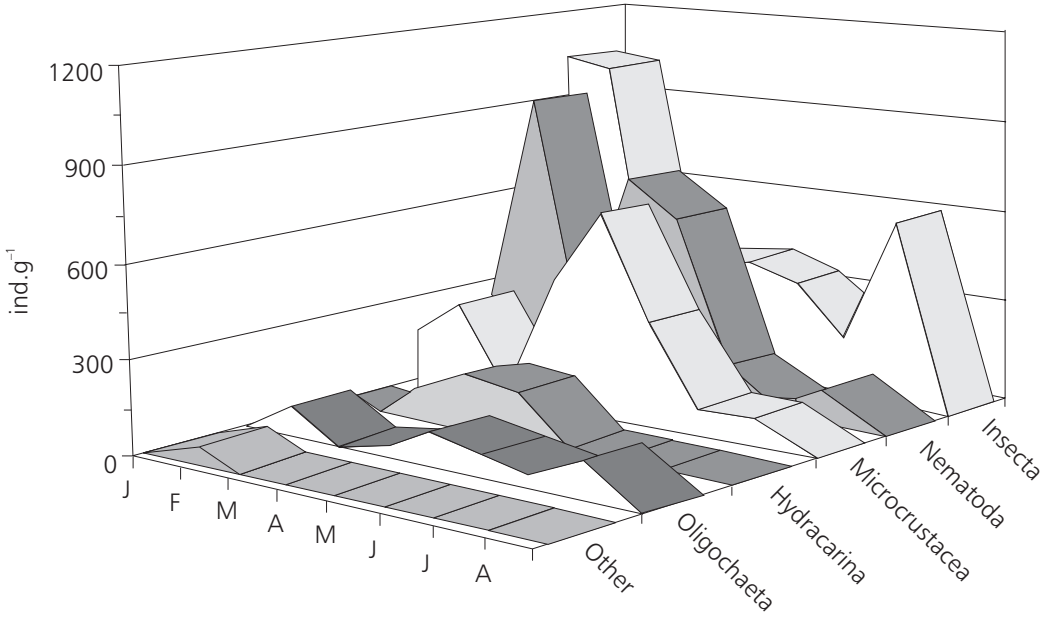

Fig. 2 - Invertebrate densities per dry weight of the macrophyte Eichhornia azurea, from January to August 1999. 


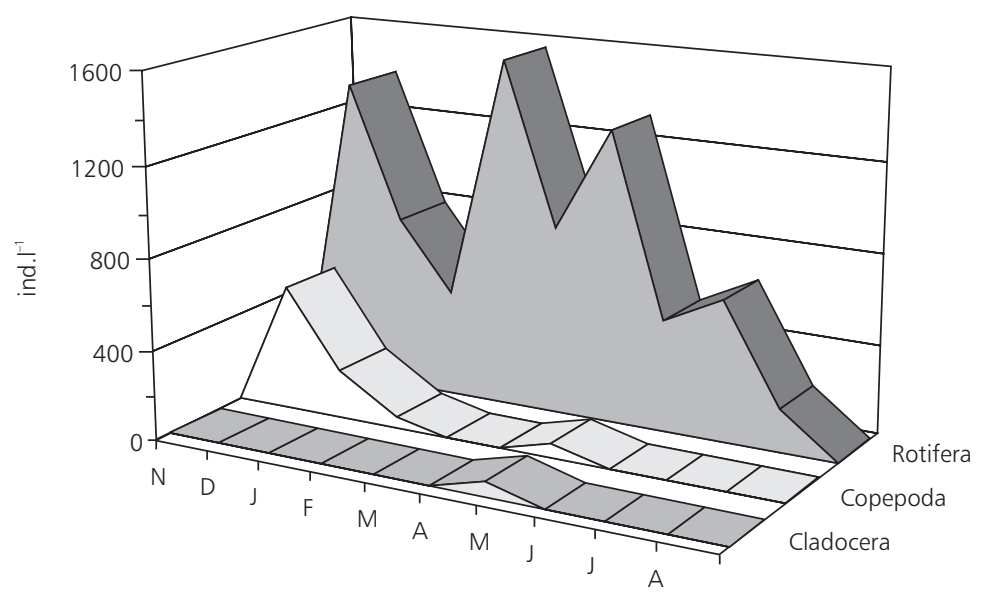

Fig. 3 - Invertebrate densities in the water nearby macrophytes, from November 1998 to August 1999.

Microcrustaceans were represented by planktonic species such as the copepod Thermocyclops decipiens and the cladocerans Daphnia gessneri and Diaphanosoma birgei, and by littoral ones such as Simocephalus sp., chydorids, and macrothricids. Approximately 12 genera of rotifers occurred: Brachionus, Collotheca, Hexarthra, Keratella, Lecane, Polyarthra, Ptygura, Trichocerca, and four unidentified ones.

\section{Fish and feeding guilds}

In macrophytes, 356 specimens belonging to 8 species were caught (Table 1). Except for 25 adult specimens of Laetacara sp. (25-37 mm), representing $18 \%$ of the total, and 1 of Pyrrhulina australis $(32 \mathrm{~mm})$, all the others were immature ones.

In the open area, the ichthyoplankton net did not catch any specimen during the whole year. In the gill nets, 35 specimens, belonging to 4 species, were caught. Except for Hoplias malabaricus (270$320 \mathrm{~mm}$ ), and 1 specimen of Geophagus brasiliensis $(137 \mathrm{~mm})$, all the others were young. Of the four species, only Cichla ocellaris did not occur in macrophytes.

The most abundant species in macrophytes were Laetacara sp. and Tilapia rendalli (Fig. 4). The latter was relatively more abundant in the warm season, peaking in December, with the first species predominating from January to August.

Contents were found in the stomachs of 263 of the 352 analyzed specimens caught in macrophytes. Their diets were composed of aquatic in- sects, microcrustaceans, rotifers, detritus, and other invertebrates (mollusks, spiders, water mites, and oligochaetes) (Fig. 5). The "other" refers to sediment, higher plants, algae, and unidentified material. Most aquatic insects were chironomid larvae and, in smaller proportion mayflies, caddisflies, and unidentified fragments of aquatic insects. Microcrustaceans comprised ostracods, a cyclopoid copepod (Eucyclops pseudoensifer), and chydorid cladocerans.

Most species fed on aquatic insects and microcrustaceans (Table 2). Astronotus ocellatus, Laetacara sp., and Pyrrhulina australis were carnivores, feeding primarily on microcrustaceans and secondarily on aquatic insects, whereas rotifers and detritus predominated in the diet of the carnivorous Tilapia rendalli.

Aquatic insects were the main dietary item for the insectivorous Geophagus brasiliensis, Gymnotus carapo, Hoplias malabaricus, and Synbranchus marmoratus. Fish larvae were consumed by G. brasiliensis, H. malabaricus, Laetacara sp., and $T$. rendalli; spiders and water mites were ingested by $P$. australis, and mollusks, mainly by $S$. marmoratus.

\section{Ontogenetic shifts in fish diet}

Larger specimens of Geophagus brasiliensis (58-137 mm) caught in the littoral near the bottom showed a more diversified diet composed of sediment, aquatic insects, other invertebrates, microcrustaceans, and scales (Fig. 6). 
TABLE 1

Range of standard length ( $\mathrm{mm})$ of species in areas with and without macrophytes.

\begin{tabular}{|c|c|c|}
\hline & Macrophytes & No macrophytes \\
\hline \multicolumn{3}{|l|}{ Order Characiformes } \\
\hline \multicolumn{3}{|l|}{ Family Erythrinidae } \\
\hline Hoplias malabaricus & $11-55$ & $270-320^{+}$ \\
\hline \multicolumn{3}{|l|}{ Family Lebiasinidae } \\
\hline Pyrrhulina australis & $7-32^{+}$ & \\
\hline \multicolumn{3}{|l|}{ Order Siluriformes } \\
\hline \multicolumn{3}{|l|}{ Suborder Gymnotoidei } \\
\hline \multicolumn{3}{|l|}{ Family Gymnotidae } \\
\hline Gymnotus carapo* & $59-62$ & \\
\hline \multicolumn{3}{|l|}{ Order Perciformes } \\
\hline \multicolumn{3}{|l|}{ Family Cichlidae } \\
\hline Astronotus ocellatus & $31-42$ & \\
\hline Cichla ocellaris & & $56-290$ \\
\hline Geophagus brasiliensis & $12-20$ & $58-137^{+}$ \\
\hline Laetacara sp. & $7-41^{+}$ & \\
\hline Tilapia rendalli & $7-33$ & $25-81$ \\
\hline \multicolumn{3}{|l|}{ Order Synbranchiformes } \\
\hline Family Synbranchidae & & \\
\hline Synbranchus marmoratus* & $45-90$ & \\
\hline
\end{tabular}

*Total length $\quad+$ Occurrence of adults

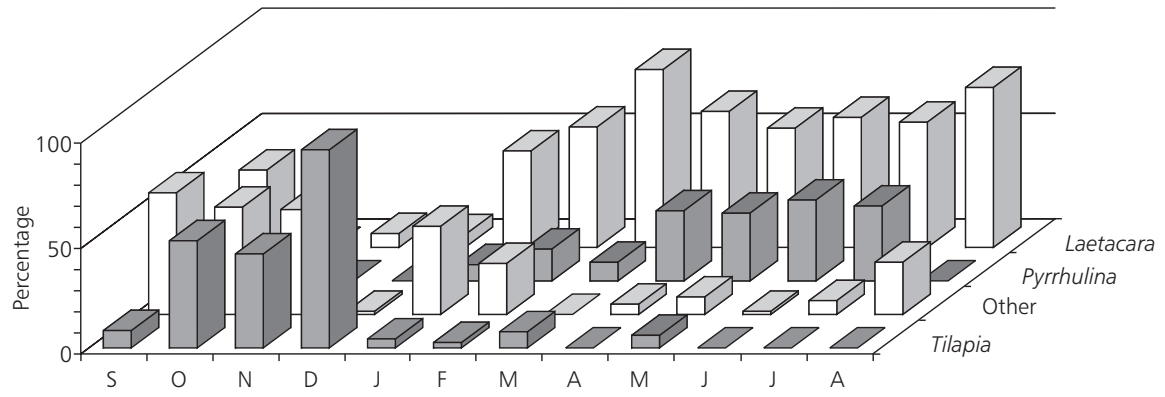

Fig. 4 - Relative abundance of fish in macrophytes, from September 1998 to August 1999.

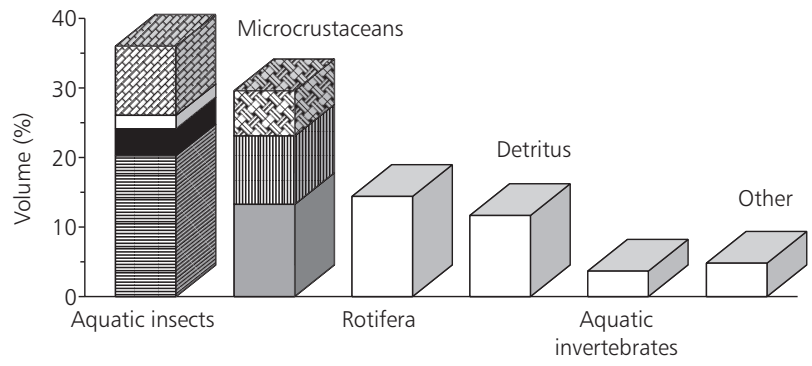
Microcrustacean
国 Chydoridae
[II Copepoda
$\square$ Ostracoda
Aquatic insects
图 Insect debris
$\square$ Trichoptera
Ephemeroptera
金 Chironomidae

Fig. 5 - Relative volume of items in the diets of the fish community in macrophytes, during the study period. 
Volume (\%) and frequency of occurrence (\%, between parentheses) of items in the diets of fish associated with macrophytes. Range of standard length (mm); $\mathbf{N}=$ specimens analyzed; $\mathbf{n}=$ specimens with stomachc content.

\begin{tabular}{|c|c|c|c|c|c|c|c|c|}
\hline & $\begin{array}{l}\text { Astronotus } \\
\text { ocellatus }\end{array}$ & $\begin{array}{l}\text { Geophagus } \\
\text { brasiliensis }\end{array}$ & $\begin{array}{l}\text { Gymnotus } \\
\text { carapo }\end{array}$ & $\begin{array}{c}\text { Hoplias } \\
\text { malabaricus }\end{array}$ & $\begin{array}{l}\text { Laetacara } \\
\text { sp. }\end{array}$ & $\begin{array}{c}\text { Pyrrhulina } \\
\text { australis }\end{array}$ & $\begin{array}{c}\text { Synbranchus } \\
\text { marmoratus }\end{array}$ & $\begin{array}{l}\text { Tilapia } \\
\text { rendalli }\end{array}$ \\
\hline SL (mm) & $31-42$ & $12-20$ & $59-62 *$ & $11-55$ & $7-41$ & $7-32$ & $45-90 *$ & $7-33$ \\
\hline $\mathbf{N}$ & 14 & 7 & 2 & 27 & 139 & 52 & 6 & 105 \\
\hline $\mathbf{n}$ & 14 & 4 & 2 & 27 & 68 & 51 & 4 & 93 \\
\hline Aquatic insects & 34.7 (93) & $80(100)$ & 99 (100) & $77.6(93)$ & $33.2(29)$ & $43.8(78)$ & $66.3(75)$ & $15.8(23)$ \\
\hline Detritus & & & & & $8.8(16)$ & $2.2(16)$ & & $26.3(33)$ \\
\hline Fish & & $20(25)$ & & $8(11)$ & $0.3(2)$ & & & $0.7(1)$ \\
\hline Higher plants & & & & & & & & $1.1(1)$ \\
\hline Microcrustaceans & $59(100)$ & & $1(50)$ & $14.4(41)$ & $44.6(69)$ & $46(88)$ & $27.5(50)$ & $11.5(21)$ \\
\hline Mollusks & $1.5(7)$ & & & & $2.7(6)$ & & $6.2(25)$ & \\
\hline Non identified & & & & & $4.3(6)$ & & & $3.8(5)$ \\
\hline Oligochaete & & & & & $4(6)$ & & & \\
\hline Rotifers & & & & & & & & $40.8(42)$ \\
\hline Sediment & $4.8(21)$ & & & & $0.5(3)$ & & & \\
\hline Spiders & & & & & & $4.6(20)$ & & \\
\hline Terrestrial insects & & & & & & $2(6)$ & & \\
\hline Water mites & & & & & $1.6(3)$ & $1.4(14)$ & & \\
\hline Feeding guilds & carnivore & insectivore & insectivore & insectivore & carnivore & carnivore & insectivore & carnivore \\
\hline
\end{tabular}

* Total length 


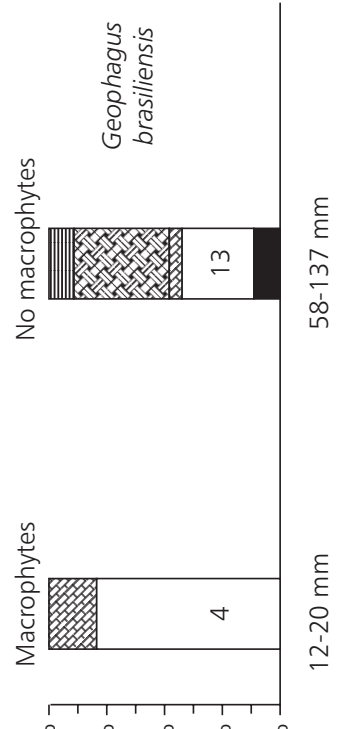

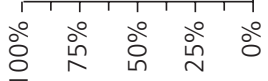

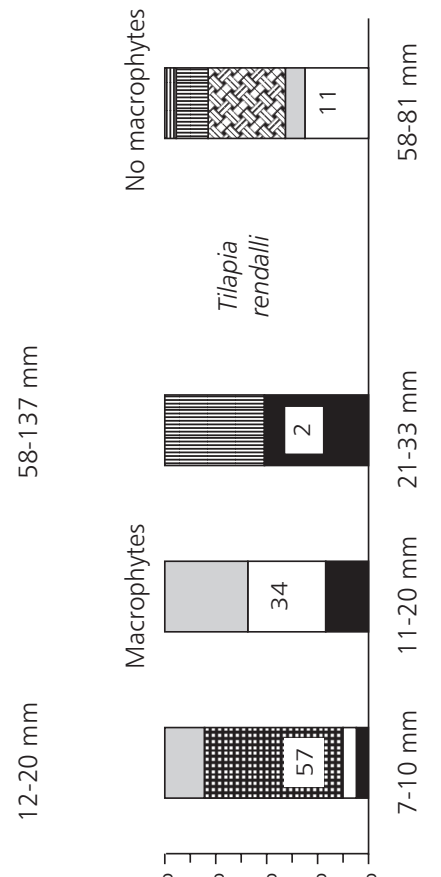

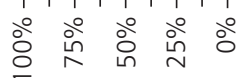

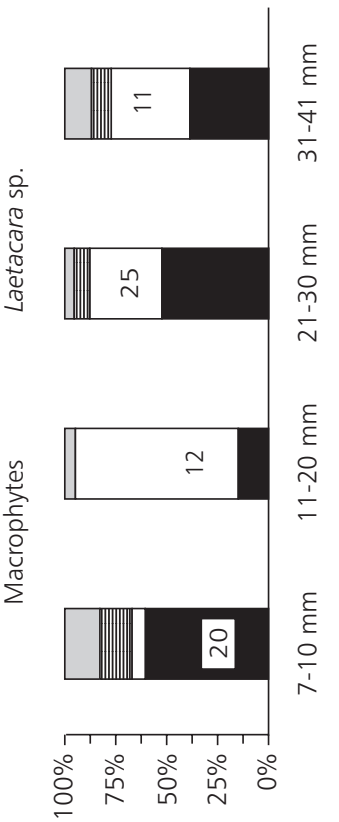

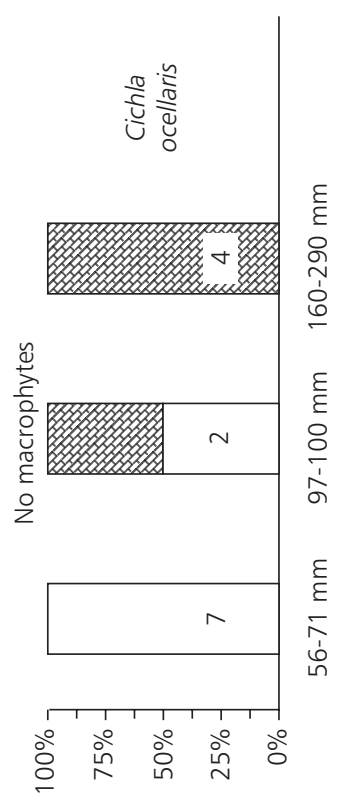

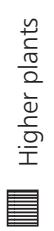

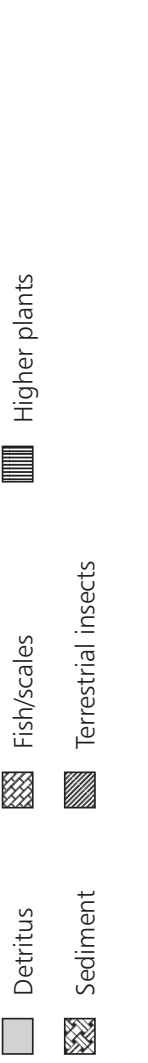

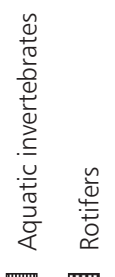

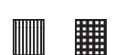

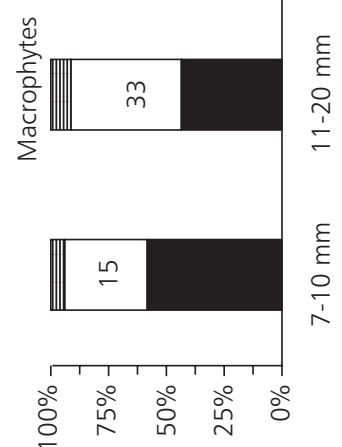


The main item in the diet of very small specimens of Hoplias malabaricus (11-20 mm), in macrophytes, were microcrustaceans, shifting to aquatic insects among the larger ones $(21-55 \mathrm{~mm})$. Adults (270-320 mm) caught in the open area had empty stomachs, but they are known to be piscivores.

The diet of Laetacara sp. caught in macrophytes was more diversified in smaller specimens $(\leq 10 \mathrm{~mm})$, but with a predominance of microcrustaceans, shifting to aquatic insects in intermediatesized specimens (11-20 mm), and to both items in larger ones (21-41 mm).

In macrophytes, the consumption of microcrustaceans decreased from small Pyrrhulina australis $(\leq 10 \mathrm{~mm})$ to large ones $(21-32 \mathrm{~mm})$, as that of aquatic insects increased. The latter specimens also included terrestrial insects in their diets.

The main dietary item of small Tilapia rendalli $(\leq 10 \mathrm{~mm})$ was rotifers, with microcrustaceans, aquatic insects, and detritus increasing in the diet of intermediate-sized specimens (11-33 mm). Specimens of 21-33 mm start eating higher plants, a dietary item of juveniles, found in areas lacking macrophytes, which consume a more diversified diet.

Cichla ocellaris exploits littoral areas lacking macrophytes, where the smallest specimens (56$71 \mathrm{~mm}$ ) found fed on aquatic insects and the largest ones $(160-290 \mathrm{~mm})$ on fish.

\section{DISCUSSION}

Five of the nine species of fish caught in Lake Monte Alegre had not previously been reported by Arcifa \& Meschiatti (1993): Astronotus ocellatus, Gymnotus carapo, Laetacara sp., Pyrrhulina australis, and Synbranchus marmoratus. Two species, Astyanax bimaculatus and Oligosarcus pintoi, had virtually disappeared from the lake; a possible explanation is predation by tucunaré, C. ocellaris, which apparently was also responsible for the disappearance of Astyanax fasciatus.

Seven of the nine species found in the lake show parental care. One with male-alone care is the nest-spawner Synbranchus marmoratus, whose males build and take care of nests (Vazzoler, 1996); another is Hoplias malabaricus, whose females lay eggs in a small depression in shallow areas, which are guarded by males (Lowe-McConnell, 1999). Some show biparental care, such as the cichlids Astronotus, Cichla ocellaris, and Tilapia rendalli. The latter is a nest-spawner (Fryer \& Iles, 1972), the first is a guarder, whose eggs are laid on a substrate, and the second one moves the larvae from a flat substrate to a nest (Zaret, 1980). Geophagus is an external bearer, whose eggs and juveniles are carried in the mouth by males or females (Zaret, 1980).

Reproductive behavior with parental care contributes to reduction of eggs and larvae in the plankton, which could explain the fact that they were not found in open areas of Lake Monte Alegre.

Macrophytes and the littoral zone are important habitats in early life stage development of most fish caught in the lake. Some species exploit the littoral and limnetic zones as they grow, depending on physical and chemical conditions (Arcifa \& Meschiatti, 1993). Tilapia rendalli provides a good example of ontogenetic variation in habitat exploitation. Larvae and small juveniles inhabit macrophytes, while exploiting nearby littoral areas lacking them as they grow. There they feed at the bottom, with adults moving also to the limnetic zone (Arcifa \& Meschiatti, 1993). In Americana Reservoir, Uieda et al. (1989) also observed specimens moving from shallow to deeper waters with growth. Geophagus brasiliensis shows behavior similar to that of Tilapia. Some species seem to live mostly on macrophytes, such as Laetacara sp. and Pyrrhulina australis, as very young specimens as well as those in maturation were found among them and were not caught by seining. Zaret (1980) reports that young Cichla ocellaris (6-7 cm SL) move to macrophytes after leaving their parents, exploiting open water when they reach $18 \mathrm{~cm}$. In Lake Monte Alegre this species was not found among macrophytes, being always caught along the littoral (this paper; Arcifa \& Meschiatti, 1993).

Aquatic insects contribute most to the diet of young fish among macrophytes of the lake, as well as to that of young and adult ones in the littoral and open water (Arcifa \& Meschiatti, 1993). Microcrustaceans and rotifers were relatively more important as dietary items in macrophytes than in areas lacking them. Accordingly, these three groups are the most abundant prey in macrophytes and 
surrounding waters. Microcrustaceans preyed on by fish larvae and juveniles among macrophytes, live among them or at the bottom and rarely in surrounding water, meaning that only a few fish leave the plants behind to pursue prey in nearby open water.

In temperate regions, some fish species are born in the littoral zone of reservoirs, migrating to the pelagic one to prey on zooplankton, and either returning or not to the littoral (Miranda \& $\mathrm{Gu}, 1998)$. In Lake Monte Alegre, larvae and young fish are not pelagial dwellers, as most species breed in the littoral. Its stands of Eichhornia azurea, although not very dense, provide a rich food supply for juveniles, more abundant than that of stands of $E$. crassipes of some floodplain lakes of the Paraná River (Neiff \& Carignan, 1997). When juveniles move away from macrophytes in the lake, rather than prey on zooplankton, they do so heavily on aquatic insects and their diets are often more diversified.

In conclusion, early life stages of fish in Lake Monte Alegre do not exert a predation pressure on the limnetic zooplankton and only low pressure on those of the littoral. The same holds for adults, except Tilapia rendalli, which are planktivores, feeding mostly on phytoplankton (Arcifa \& Meschiatti, 1993, 1996).

Acknowledgments - We thank A. Perticarrari, A. S. FerrãoFilho, C. Fileto, M. S. M. Castilho, A. L. A. Melo, and A. C. Ribeiro for help in the field work, and A. L. M. Melo, R. Benini for fish identifications and C. G. Froehlich for insect identifications. Thanks are also due to FAPESP for financial support (97/10407-6) and a grant to A. J. M. (98/06348-7).

\section{REFERENCES}

ARAÚJO-LIMA, C. A. R. M., PORTUGAL, L. P. S. \& FERREIRA, E. G., 1986, Fish-macrophyte relationship in the Anavilhanas Archipelago, a black water system in the Central Amazon. J. Fish Biol., 2: 1-11.

ARAÚJO-LIMA, C. A. R. M., AGOSTINHO, A. A. \& FABRÉ, N. N., 1995, Trophic aspects of fish communities in Brazilian rivers and reservoirs, pp. 105-136. In: J. G. Tundisi, C. E. M. Bicudo \& T. Matsumura-Tundisi (eds.), Limnology in Brazil. Rio de Janeiro, ABC/SBL, 376p.

ARCIFA, M. S. \& MESCHIATTI, A. J., 1993, Distribution and feeding ecology of fishes in a Brazilian Reservoir: Lake Monte Alegre. Interciencia, 18: 302-313.

ARCIFA, M. S. \& MESCHIATTI, A. J., 1996, Tilapia rendalli in the Lake Monte Alegre, a case of planktivory. Acta Limnol. Brasil., 8: 221-229.
ARCIFA, M. S. \& NORTHCOTE, T. G., 1997, Need for holistic approaches in food web experiments and biomanipulation in tropical lakes: a Brazilian reservoir experience. Verh. Internat. Verein. Limnol., 26: 661-665.

ARCIFA, M. S., MESCHIATTI, A. J., GOMES, E. A. T., 1990, Thermal regime and stability of a tropical shallow reservoir: Lake Monte Alegre, Brazil. Rev. Hydrobiol. trop., 23: 271-281.

ARCIFA, M. S., GOMES, E. A. T. \& MESCHIATTI, A. J., 1992, Composition and fluctuations of the zooplankton of a tropical Brazilian reservoir. Arch. Hydrobiol., 123: 479-495.

ARCIFA, M. S., SILVA, L. H. S. \& SILVA, M. H. L., 1998, The planktonic community in a tropical Brazilian reservoir: composition, fluctuations and interactions. Rev. Brasil. Biol., 58: 241-254.

CONROW, R., ZALE, A. V. \& GREGORY, R. W., 1990, Distributions and abundances of early life stages of fishes in a Florida Lake dominated by aquatic macrophytes. Trans. Amer. Fish. Soc., 119: 521-528.

FLOYD, K. P., HOYT, R. D. \& TIMBROOK, S., 1984, Chronology of appearance and habitat partitioning by stream larval fishes. Trans. Amer. Fish. Soc., 113: 216-223.

FRYER, G. \& ILES, T. D., 1972, The cichlid of the great lakes of Africa: their biology and evolution. Neptune City, T. H. P., 641p.

HYSLOP, E. J., 1980, Stomach content analysis, a review of methods and their application. J. Fish Biol., 17: 411429.

LOWE-McCONNELL, R. H., 1999, Estudos ecológicos de comunidades de peixes tropicais. Edusp, São Paulo, 535p.

MACHADO-ALLISON, A. \& GARCIA, C., 1986, Food habits and morphological changes during ontogeny in three serrasalmin fish species of the Venezuelan floodplains. Copeia, 1986: 193-196.

MESCHIATTI, A. J., ARCIFA, M. S. \& FENERICH-VERANI, N., 2000, Ecology of fish in oxbow lakes of Mogi-Guaçu River, pp. 817-830. In: J. E. Santos \& J. S. R. Pires (eds.), Estudos integrados em ecossistemas: Estação Ecológica de Jataí, RiMa Editora, São Carlos, 900p.

MIRANDA, L. E. \& GU, H., 1998, Dietary shifts of a dominant reservoir planktivore during early life stages. Hydrobiologia, 377: 73-83.

MOL, J. H., 1995, Ontogenetic diet shifts and diet overlap among three closely related neotropical armoured catfishes. J. Fish Biol., 47: 788-807.

NAKATANI, K., BAUMGARTNER, G. \& CAVICCHIOLI, M., 1997, Ecologia de ovos e larvas de peixes, pp. 281306. In: A. E. A. M. Vazzoler, A. A. Agostinho \& N. S. Hahn (eds.), A planície de inundação do Alto Rio Paraná: aspectos físicos, biológicos e socioeconômicos. EDUEM/Nupélia, Maringá, 460p.

NEIFF, A. P. de \& CARIGNAN, R., 1997, Macroinvertebrates on Eichhornia crassipes roots in two lakes of the Paraná River floodplain. Hydrobiologia, 345: 185-196. 
PALLER, M. H., 1987, Distribution of larval fish between macrophyte beds and open channels in a Southeastern floodplain swamp. J. Fresh. Ecol., 4: 191-200.

PETERING, R. W. \& VAN DEN AVYLE, M. J., 1988, Relative efficiency of a pump for sampling larval gizzard and threadfin shad. Trans. Amer. Fish. Soc., 117: 78-83.

SABO, M. J. \& KELSO, W. E., 1991, Relationship between morphometry of excavated floodplain ponds along the Mississipi River and their use as fish nurseries. Trans. Amer. Fish. Soc., 120: 552-561.

SANTOS, G. M. dos \& FERREIRA, E. J. G., 1999, Peixes da Bacia Amazônica, pp. 345-373. In: R. H. LoweMcConnell, Estudos ecológicos de comunidades de peixes tropicais. Edusp, São Paulo, 535p.

SAZIMA, I. \& ZAMPROGNO, C., 1985, Use of water hyacinths as shelter, foraging place, and transport by young piranhas, Serrasalmus spilopleura. Env. Biol. Fish., 12: 237-240
TURNER, T. F., TREXLER, J. C., MILLER, G. L. \& TOYER, K. E., 1994, Temporal and spatial dynamics of larval and juvenile fish abundance in a temperate floodplain river. Copeia, 1994: 174-183.

UIEDA, V. S., UIEDA, W., FROEHLICH, O. \& AMARAL, M. E. C., 1989, Organização de cardumes em Tilapia rendalli na Represa de Americana, São Paulo. Rev. Brasil. Biol., 49: 749-756.

VAZZOLER, A. E. A. M., 1996, Biologia da reprodução de peixes teleósteos: teoria e prática. EDUEM, Maringá, $169 \mathrm{p}$.

ZARET, T. M. \& RAND, A. S., 1971, Competition in tropical stream fishes: support for the competitive exclusion principle. Ecology, 52: 336-342.

ZARET, T. M., 1980, Life history and growth relationships of Cichla ocellaris, a predatory South American cichlid. Biotropica, 12: 144-157. 